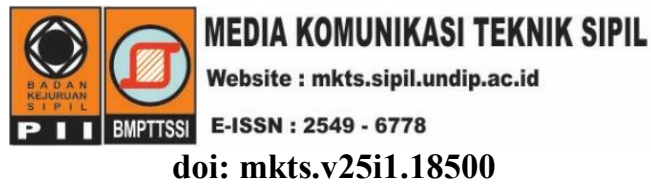

\title{
Kualitas Beton SCC dengan Substitusi Agregat Halus Tailing Tambang Emas Daerah Pongkor
}

\author{
*Amalia, Muhtarom Riyadi \\ Jurusan Teknik Sipil, Politeknik Negeri Jakarta \\ *) amalia@sipil.pnj.ac.id
}

Received: 12 April 2018 Revised: 8 Mei 2019 Accepted: 13 Mei 2019

\begin{abstract}
This paper presents the results of self compacting concrete (SCC) with water cement ratio 0.30 with four variations of tailings, ie 0\%,5\%,10\% and 15\%. Superplastisizer used is a type Naptha 511P of PT.Karya Naptha Belide. The results showed that (1) The use of tailings as fine aggregate in concrete SCC, has good workability. The fresh concrete that uses tailings, passing ability and filling ability is decrease. The use of tailings up to 15\% of eligible properties filling ability and passing ability of SCC, (2) The more tailings used in SCC, setting time of concrete becomes longer, (3) Concrete with tailings as fine aggregate have unit weight is smaller than the concrete with fine aggregate sand, (4) Concrete with tailings has higher compressive strength and modulus of elasticity than concrete without tailings, (5)The use of tailings in concrete can lower tensile strength of concrete, (6)The optimum replacement of tailing found to be 10\% in the concrete.
\end{abstract}

Keywords: Self compacting concrete, tailing, compressive strength, tensile strength

\begin{abstract}
Abstrak
Makalah ini menyajikan hasil penelitian kualitas beton SCC dengan faktor air semen (fas) 0,30 dengan empat variasi tailing, yaitu 0\%, 5\%, 10\%, dan 15\% sebagai substitusi agregat halus. Superplastisizer yang digunakan adalah jenis Naptha 511P dari PT. Karya Naptha Belide. Hasil penelitian menunjukkan bahwa (1) Penggunaan tailing sebagai agregat halus pada beton SCC, mempunyai workability yang baik. Semakin besar penambahan tailing dapat menurunkan sifat kemampuan lolos (passing ability) dan kemampuan mengisi celah-celah diantara tulangan (filling ability). Penggunaan tailing sampai dengan $15 \%$ masih memenuhi syarat sifat sifat kemampuan lolos (passing ability) dan kemampuan mengisi celah-celah diantara tulangan (filling ability) beton SCC, (2) Semakin tinggi kadar tailing sebagai bahan tambah pada beton SCC, waktu ikat awal pada beton semakin lama, (3) Beton dengan agregat halus tailing mempunyai berat isi lebih kecil dibandingkan dengan beton dengan agregat halus pasir, (4) Beton dengan substitusi tailing mempunyai kuat tekan dan modulus elastisitas lebih tinggi dibandingkan beton tanpa tailing, (5)Penggunaan tailing pada beton dapat menurunkan kuat tarik beton, (6) Komposisi optimum jumlah tailing pada beton adalah sebesar 10\% dari berat agregat halus.
\end{abstract}

Kata kunci: Beton SCC, tailing, kuat tekan, kuat tarik

\section{Pendahuluan}

Pada pekerjaan konstruksi saat ini, dibutuhkan beton yang mudah dikerjakan, mudah dipompa dan dapat mengalir mengisi celah-celah tulangan yang terpasang rapat sehingga dihasilkan beton yang padat dan awet. Karena adanya tuntutan seperti ini, maka saat ini dikembangkan beton dengan pemadatan sendiri (self compacting concrete/SCC). Pada SCC, beton tidak perlu digetar dengan alat penggetar (vibrator) karena beton akan memadat sendiri dengan gravitasi ke ruang yang terkecil dalam bekisting, sehingga tidak menghasilkan suara bising dan tenaga kerja yang lebih sedikit. Penggunaan SCC akan menghasilkan beton yang memiliki kekuatan dan keawetan (durabilitas) yang lebih baik dari beton konvensional. Pembuatan SCC, membutuhkan fraksi butiran agregat yang lebih kecil dengan jumlah lebih banyak dibandingkan beton konvensional, agar beton segar dapat dipompa dan memadat sendiri. Salah satu alternatif agregat yang dapat digunakan untuk membuat SCC adalah tailing limbah penambangan emas. Secara fisik, tailing merupakan batuan 
berbentuk pasir halus sampai sedang dengan komposisi bahan $\pm 75 \%$ kuarsa, $23 \%$ oksida besi dan $2 \%$ mineral lain.

Dari hasil uji laboratorium, tailing mempunyai berat jenis 2,7 dengan gradasi masuk zona 2 sesuai British Standar. Penambangan emas yang dilakukan masyarakat di daerah Pongkor menghasilkan tailing yang jumlahnya cukup besar. Masyarakat setempat melakukan penambangan dengan cara menggali tanah dan mengambil batuan yang mengandung emas. Batuan tersebut diolah dan dihancurkan untuk memisahkan emasnya. Pada proses penambangan emas, tailing merupakan limbah yang jumlahnya sangat besar, karena dari penambangan yang dilakukan, hanya kurang dari $3 \%$ yang menghasilkan emas, sisanya berupa limbah tailing. Sampai saat ini, tailing belum dimanfaatkan secara optimal oleh penduduk setempat.

Penelitian penggunaan tailing sebagai bahan perkerasan jalan menyebutkan bahwa tailing yang dimanfaatkan sebagai campuran perkerasan jalan sampai $40 \%$ dapat memperbaiki sifat tanah dasar jalan (Saing, 2008). Hasil penelitian penggunaan tailing sebagai bahan pengisi pada bata beton berlubang menyebutkan bahwa, tailing dapat digunakan sebagai pengganti agregat sampai dengan $75 \%$, dimana pada komposisi tersebut menghasilkan bata beton berlubang yang masih memenuhi standar SNI untuk bata beton kelas IV yang dapat digunakan sebagai dinding penyekat non struktural (Amalia \& Murdiyoto, 2013). Dari beberapa hasil penelitian tersebut, ada beberapa hal yang masih perlu dikembangkan lebih lanjut, yaitu pemanfaatan tailing sebagai substitusi agregat halus pada beton yang dapat mengalir dan memadat sendiri. Adapun permasalahan yang dibahas adalah kualitas beton SCC dengan tailing sebagai substitusi agregat halus, terdiri dari: (a) Sifat-sifat beton segar SCC yang menggunakan tailing penambangan emas sebagai substitusi agregat halus, (b) Perilaku mekanis SCC dalam memikul beban. Perilaku mekanis yang diteliti terdiri dari: kuat tekan, kuat tarik belah, dan modulus elastisitas, (c) Prosentase optimum tailing sebagai substitusi agregat halus pada SCC.

SCC merupakan istilah yang digunakan untuk beton yang dapat memadat sendiri tanpa dilakukan penggetaran. Tujuan penggunaan SCC adalah untuk mendapatkan beton dengan performa tinggi, yaitu: (1) dalam keadaan segar (fresh concrete), beton dapat memadat sendiri tanpa dilakukan penggetaran, (2) pada umur dini, beton tidak mudah retak karena penyusutan, (3) pada beton keras, mempunyai kuat tekan dan keawetan (durabilitas) yang tinggi.
Perbedaan utama antara beton konvensional dengan SCC adalah pada beton segar dengan nilai faktor air semen (FAS) rendah, SCC dapat memadat sendiri tanpa penggetaran, sedangkan pada beton konvensional beton dalam kondisi kental sehingga sulit untuk dikerjakan. Campuran beton dikatakan SCC, jika mempunyai sifat: kemampuan mengisi celah-celah diantara tulangan (filling ability), kemampuan lolos (passing ability), dan ketahanan terhadap pemisahan butiran/ segregasi (segregation resistance). Untuk memenuhi sifat-sifat di atas, maka pada SCC membutuhkan bahan tambah kimia dengan jenis superplastisizer dan fraksi agregat yang berbutiran halus lebih banyak dibandingkan dengan beton konvensional. Penelitian Okamura \& Ouchi (2003) menyebutkan bahwa pada SCC membutuhkan agregat halus $60 \%$ dan dosis superplastisizer lebih tinggi dibandingkan beton konvensional. Untuk menghasilkan SCC dengan performa tinggi dibutuhkan agregat kasar dengan diameter maksimum 18 mm (Collepardi, 2005).

Alat untuk mengukur kemudahan dikerjakan (workability) pada SCC segar ada beberapa macam, diantaranya: slump flow by Abrams Cone, $T 50 \mathrm{~cm}$ slump flow, L-Box, V-funnel, U-box, J-ring, Orimet. Biasanya untuk pengujian di lapangan dilakukan pengujian slump flow test $\mathrm{T} 50 \mathrm{~cm}$ dengan menggunakan kerucut Abrams, karena alatnya sederhana dan mudah dioperasikan. Pengujian beton segar harus disesuaikan dengan persyaratan SCC, yaitu: filling ability, passing ability, dan segregation resistance. Nilai slump flow didapat dengan mencatat waktu dimana diameter sebaran beton sebesar $50 \mathrm{~cm}$ jika waktu yang dicapai $2-5$ detik.

Perkembangan penelitian tentang beton SCC dan tailing selama 10 tahun terakhir diuraikan sebagai berikut: Penelitian Okamura dan Ouchi (2003) membahas tentang proporsi campuran (mix design) pada beton SCC yang menggunakan campuran agregat halus pasir alam. Hasil penelitian menyebutkan bahwa pada beton SCC, proporsi agregat di dalam campuran lebih kecil dibandingkan pada beton konvensional.

Jumlah agregat kasar sebesar 50\% pada SCC, menghasilkan deformasi beton menjadi kecil. Hasil penelitian yang sama juga menyebutkan bahwa proporsi agregat halus di dalam mortar SCC yang menghasilkan deformasi geser beton kecil adalah sebesar $60 \%$. Untuk mencegah pemisahan butiran agregat kasar dan pasta/mortar beton pada saat campuran mengisi celah diantara tulangan dan beton dapat memadat sendiri dengan baik, langkah yang dapat dilakukan adalah dengan menggunakan jumlah agregat lebih sedikit, rasio antara air dan mineral halus (water-powder) rendah, dan 
menggunakan superplastisizer. Perbandingan antara jumlah air dan bahan tambah mineral adalah 0,90 sampai 1,0 (Okamura \& Ouchi , 2003).

Penelitian Collepardi (2005) membahas tentang SCC dengan bahan campuran fly ash, bubuk batu kapur (ground limestone), dan agregat batu pecah dengan diameter maksimum $18 \mathrm{~mm}$. Hasil penelitian menyebutkan bahwa beton SCC yang menggunakan fly ash mempunyai kuat tekan lebih tinggi dibandingkan dengan SCC yang menggunakan bubuk batu kapur pada umur di atas 28 hari. Hal ini terjadi karena efek puzzolan dari fly ash yang memperlambat pengikatan semen portland pada beton muda. SCC yang menggunakan campuran fly ash dan bubuk batu kapur mempunyai kuat tekan yang paling tinggi. Selain itu, SCC dengan komposisi campuran ini menghasilkan panas hidrasi rendah, dan mempunyai penyusutan yang relatif sama, baik campuran dengan fly ash, bubuk batu kapur, maupun campuran fly ash dan bubuk batu kapur (Collepardi, 2005).

Penggunaan fly ash sebagai bahan tambah pada beton SCC menghasilkan kuat tekan beton yang tinggi. Hal ini sesuai dengan hasil penelitian

Borsoi, et al (2007) yang menyebutkan bahwa penggunaan fly ash sebesar 50\% menggantikan semen portland pada beton SCC menghasilkan beton dengan kuat tekan $75 \mathrm{MPa}$ pada umur 90 hari. Penggunaan fly ash bersama-sama dengan mikrosilika (ultra fine amorphous colloidal silica) pada beton SCC dapat menghasilkan beton dengan kuat tekan di atas $80 \mathrm{MPa}$ dengan panas hidrasi yang rendah (Collepardi et al., 2007).

Bahan tambah mineral lain yang dapat digunakan pada beton SCC adalah Ground Granulated Blast Slag (GGBS). GGBFS dapat berupa iron slag (terak besi), steel slag (terak baja), nickel slag (terak nikel) dan copper slag (terak tembaga). Komposisi GGBFS terdiri dari : $\mathrm{CaO}, \mathrm{SiO}_{2}, \mathrm{Al}_{2} \mathrm{O}_{3}$ dan $\mathrm{Fe}_{2} \mathrm{O}_{3}$. Penggunaan slag pada beton SCC dapat meningkatkan kuat tekan beton pada umur muda.

Hal ini sesuai dengan hasil penelitian Borsoi, et al (2007) yang menyebutkan bahwa penggunaan slag pada SCC dapat menghasilkan beton dengan kuat tekan $82 \mathrm{MPa}$, lebih tinggi dibandingkan menggunakan fly ash. Hasil penelitian yang sama juga menyebutkan bahwa penggunaan slag dan fly ash secara bersama-sama dapat menghasilkan kuat tekan beton paling tinggi sebesar $85 \mathrm{MPa}$.

Selain bahan tambah mineral yang sudah disebutkan, bahan lain yang dapat digunakan pada beton SCC adalah bubuk kapur (ground limestone). Penggunaan bubuk kapur pada SCC menghasilkan beton dengan kuat tekan $58 \mathrm{MPa}$ pada umur 28 hari (Troli, R. et al., 2005). Hasil penelitian Collepardi (2005) menyebutkan bahwa penggunaan fly ash dan bubuk kapur dapat menghasilkan beton dengan kuat tekan 30-40 MPa pada umur 28 hari.

Borsoi, et al (2006) meneliti pengaruh viscocity modifying admixture (VMA) pada SCC yang menggunakan filler bubuk batu kapur (ground limestone), pasir alam ukuran 0-4 mm, dan kerikil 4-16 mm. Hasil penelitian menunjukkan bahwa dibutuhkan VMA sebanyak 2 liter $/ \mathrm{m}^{3}$ untuk menghasilkan SCC yang encer dengan slump flow $700 \mathrm{~mm}$. Apabila pada SCC tidak menggunakan ground limestone, maka dibutuhkan dosis VMA lebih tinggi, yaitu sebesar 7 liter/ $\mathrm{m}^{3}$. Dengan kata lain, VMA dapat berfungsi sebagai filler cair menggantikan filler mineral padat.

Grdić et al (2008) meneliti SCC dengan berbagai jenis aditif, yaitu fly ash, silicafume, kapur hidrolik, dan campuran antara kapur hidrolik dan fly ash. Hasil penelitian menunjukkan bahwa SCC yang menggunakan campuran fly ash dan kapur hidrolik mempunyai fluiditas paling baik dan kuat tekan paling tinggi. SCC dengan kuat tekan paling rendah dihasilkan oleh campuran yang menggunakan fly ash. Dhiyaneshwaran et al (2013) meneliti sifat durabilitas SCC dengan bahan tambah fly ash. Penelitian dilakukan dengan membuat campuran SCC menggunakan substitusi fly ash, 0\%, 10\%, $20 \%, 30 \%$, 40\%, dan $50 \%$ dari berat semen. Hasil penelitian ini menunjukkan bahwa SCC dengan substitusi fly ash 30\% menghasilkan fluiditas, sifat mekanik dan durabilitas paling baik.

Dubey \& Kumar (2012) meneliti SCC menggunakan bahan tambah silicafume dan fly ash dengan berbagai variasi dosis superplastisizer (SP). Hasil penelitian menunjukkan bahwa, penggunaan dosis SP di atas 2\% dari berat mineral (semen, fly ash dan silicafume) menurunkan kuat tekan dan waktu ikat beton semakin lama. Dosis SP yang optimum pada beton SCC maksimum 2\%. Atan \& Awang (2011) meneliti penggunaan abu sekam padi sebagai pengganti semen sebesar $15 \%$ pada SCC menghasilkan kuat tekan $40 \mathrm{MPa}$.

Penggunaan abu sekam padi bersama-sama dengan bubuk batu kapur sebagai pengganti semen pada beton SCC menghasilkan kuat tekan beton sebanding dengan beton SCC tanpa abu sekam padi dan meningkatkan kuat lentur (Atan \& Awang 2011). Bouziani et al (2012) meneliti penggunaan pasir gurun sebagai substitusi agregat halus pada beton SCC.

Hasil penelitian menyebutkan bahwa penggunaan pasir gurun $10 \%$ dan $90 \%$ pasir sungai 
menghasilkan beton SCC yang mempunyai fluiditas paling baik dan kuat tekan paling tinggi. Berdasarkan pengkajian terhadap jurnal-jurnal penelitian tentang beton SCC dan tailing penambangan emas yang telah dilakukan oleh peneliti lain selama 10 tahun terakhir, belum didapatkan beton SCC yang menggunakan bahan tambah maupun bahan pengisi tailing penambangan emas yang mempunyai workability tinggi, durabilitas baik, dan kekuatan yang tinggi di dalam memikul beban. Pada tulisan ini, dibahas tentang kualitas beton SCC yang menggunakan tailing sebagai substitusi agregat halus.

\section{Metode}

\section{Variasi dan jenis benda uji}

Sifat beton SCC segar yang diteliti meliputi workability, waktu ikat, dan berat isi beton segar. Untuk menguji sifat workability SCC segar dilakukan pengujian kemampuan mengalir (flowability) dan kemampuan mengisi celah-celah diantara tulangan (passing ability). Untuk menguji sifat flowability digunakan alat slump flow $T 50 \mathrm{~cm}$, sedangkan untuk menguji sifat passing ability menggunakan alat $L$-Box.

Metode pengujian sifat SCC segar mengacu pada standar European Federation of National Associations Representing for Concrete (EFNARC) tahun 2002. Benda uji untuk meneliti kuat tekan dan kuat tarik beton SCC keras, berupa silinder beton $\varnothing 15 \mathrm{~cm}$, tinggi $30 \mathrm{~cm}$. Benda uji dibuat dengan empat variasi jumlah tailing sebagai substitusi agregat halus, yaitu $0 \%, 5 \%, 10 \%$, dan $15 \%$. Masing-masing variasi dilakukan pengulangan sebanyak tiga kali. Untuk menguji perkembangan kuat tekan beton dilakukan pengujian pada umur 3, 7, 14, dan 28 hari. Kuat tarik dan modulus elastisitas beton diuji pada umur 28 hari.

Sebelum dilakukan pengujian sifat beton SCC keras, semua benda uji dirawat (curing) dengan direndam di dalam air pada suhu ruangan sampai dilakukan pengujian. Bahan yang digunakan dalam penelitian ini adalah bahan perekat jenis portland composite cement (PCC), agregat halus dari jenis pasir alam, dan limbah tailing penambangan emas di daerah Pongkor, Bogor, Jawa Barat, Superplastisizer jenis Naptha 511P dari PT.Karya Naptha Belide.

\section{Metode pengujian bahan}

Sebelum dilakukan pembuatan benda uji beton, dilakukan pengujian terhadap mutu agregat halus, dan sifat fisik tailing. Untuk sifat-sifat PC tidak dilakukan pengujian karena digunakan PC yang memenuhi standar SNI. Jenis dan standar pengujian yang digunakan meliputi: pengujian agregat halus, agregat kasar, dan tailing meliputi: berat jenis dan penyerapan air sesuai standar pengujian American Standard Testing and material (ASTM C - 128 93), berat isi asli (ASTM C - 29/C 29 M - 91a ), analisa ayak (ASTM C - 136 - 96a), kadar air (ASTM C - 566 - 97), kadar lumpur (ASTM C 117 - 95). Pengujian terhadap workability SCC segar meliputi: flowability - slump flow $750 \mathrm{~cm}$ dan passing ability \& segregation ressistance $-L-B o x$ (EFNARC).

Pengujian beton SCC keras meliputi: kuat tekan, kuat tarik, dan kuat lentur mengacu pada metode ASTM. Setelah dilakukan pengujian terhadap bahan-bahan penyusun beton, prosedur selanjutnya adalah membuat rancang campuran beton SCC, pembuatan benda uji dan pengujian kualitasnya.

\section{Hasil dan Pembahasan}

\section{Sifat-sifat bahan penyusun beton}

Sifat-sifat bahan penyusun beton SCC disajikan pada Tabel 1, dan bahan-bahan yang digunakan untuk membuat beton SCC memenuhi standar yang dipersyaratkan. Dari hasil pengujian terhadap bahan-bahan penyusun beton SCC terlihat, bahwa semua bahan yang digunakan memenuhi syarat untuk membuat beton SCC. Berat jenis pasir akan mempengaruhi kekuatan beton SCC. Pasir dengan berat jenis tinggi dapat meningkatkan kuat tekan beton. Pasir yang digunakan dalam penelitian ini memiliki berat jenis 2,64.

Dilihat dari berat jenisnya, pasir ini memenuhi syarat sebagai agregat normal, yaitu 2,50-2,70. Limbah tailing mempunyai berat jenis 2,67. Berat isi pasir berfungsi untuk menghitung kebutuhan bahan yang akan digunakan untuk membuat adukan. Berat isi pasir yang digunakan dalam penelitian ini adalah $1334,82 \mathrm{~kg} / \mathrm{m}^{3}$, dimana nilai ini memenuhi persyaratan ASTM C 331 yaitu minimum $1120 \mathrm{~kg} / \mathrm{m}^{3}$.

Kadar air menunjukkan kandungan air yang ada di dalam pasir, sedangkan penyerapan air adalah kemampuan pasir dalam menyerap air sampai kondisi jenuh. Jika nilai kadar air pasir nilainya lebih kecil dari penyerapannya, maka pasir dalam kondisi kering. Sebaliknya jika kadar air pasir lebih tinggi dibandingkan penyerapan airnyamaka pasir dalam kondisi basah. Kadar air dan penyerapan air pasir berpengaruh terhadap kebutuhan air dalam membuat adukan beton SCC yang mudah dikerjakan (workable). Hasil uji laboratorium, pasir yang digunakan dalam kondisi basah, sedangkan tailing dalam kondisi kering. 
Tabel 1. Sifat-sifat bahan penyusun beton SCC

\begin{tabular}{lcrr}
\hline \multicolumn{1}{c}{ Sifat bahan } & Agregat halus & Tailing & Agregat kasar \\
\hline Berat jenis & 2,48 & 2,22 & 2,39 \\
Berat jenis (SSD) & 2,52 & 2,43 & 2,48 \\
Berat jenis semu & 2,60 & 2,81 & 2,65 \\
Berat isi lepas $\left(\mathrm{kg} / \mathrm{m}^{3}\right)$ & $1.267,72$ & $1.055,51$ & $1.403,47$ \\
Berat isi padat $\left(\mathrm{kg} / \mathrm{m}^{3}\right)$ & $1.442,79$ & $1.158,49$ & $1.514,24$ \\
Penyerapan air $(\%)$ & 1,89 & 2,46 & 4,12 \\
Kadar air $(\%)$ & $4,27 \%$ & 2,22 & $2,45 \%$ \\
Finenes modulus $(\%)$ & $2,63 \%$ & 2,43 & 6,04 \\
Analisa ayak & Zona 2 & Zona 2 & Diameter mak $10 \mathrm{~mm}$ \\
Kadar lumpur $(\%)$ & 2,80 & 1,58 & 0,82 \\
\hline
\end{tabular}

Gradasi agregat merupakan susunan butiran agregat, baik agregat halus maupun agregat kasar. Gradasi agregat sangat berpengaruh terhadap workability beton SCC dan kekuatan yang dihasilkan. Dilihat dari gradasinya, agregat halus yang digunakan memenuhi syarat untuk gradasi pasir zona 2, sedangkan agregat kasar memenuhi syarat untuk agregat dengan diameter agregat maksimum $10 \mathrm{~mm}$.

Workability merupakan sifat beton segar untuk menunjukkan kemudahan beton diaduk, dituang, dicetak, dan dipadatkan. Sifat ini dipengaruhi oleh kelecakan, daya menahan air, dan plastisitas adukan beton segar yang tidak terlepas dari sifat bahan dan kehalusan agregat. Campuran beton SCC dalam kondisi segar harus mempunyai sifat-sifat: filling ability atau kemampuan mengisi, passing ability atau kemampuan lolos, dan segregation ressistance atau ketahanan terhadap segregasi.

Pada penelitian ini, sifat filling ability beton SCC diuji dengan alat slump flow test $T 50 \mathrm{~cm}$, sedangkan sifat passing ability dengan alat L-Box. Hasil penelitian filling ability dan passing ability beton SCC dengan agregat tailing, disajikan dalam Gambar 1 dan 2.

Filling ability merupakan kemampuan adukan beton segar untuk mengisi ruang atau rongga. Dari Gambar 1 terlihat bahwa, penggunaan tailing dalam campuran beton sebagai substitusi agregat halus pada beton SCC menyebabkan fluiditas beton SCC turun. Hal ini terlihat dari waktu yang diperlukan aliran beton untuk mencapai diameter $50 \mathrm{~cm}$ semakin lama. Penggunaan tailing juga menyebabkan slump flow beton SCC turun. Selain itu, semakin banyak tailing yang menggantikan pasir pada beton SCC, maka filing ability beton tersebut semakin kecil.

Namun demikian, penggunaan tailing sebagai substitusi agregat halus sampai dengan $15 \%$, filling ability beton tersebut masih memmenuhi syarat yang ditentukan oleh EFNARC, yaitu sebesar 2-5 detik. Dengan demikian, penggunaan tailing sebagai substitusi agregat halus pada beton SCC masih memenuhi syarat. Pada pengujian slump flow $\mathrm{T} 50 \mathrm{~cm}$, juga terlihat homogenitas beton.

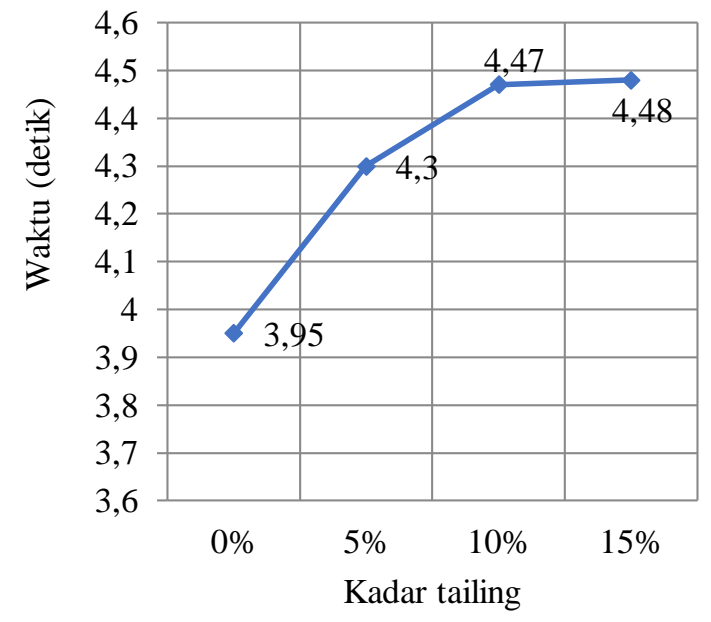

Gambar 1. Filling ability beton tailing dengan slump flow test $\mathrm{T} 50 \mathrm{~cm}$

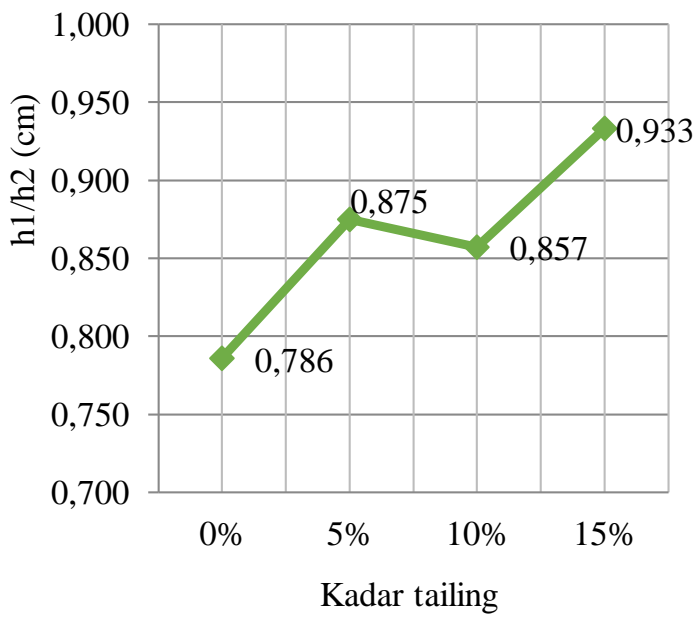

Gambar 2. Passing ability beton tailing dengan L-Box 
Penambahan tailing tidak menyebabkan segregasi dan bleeding beton segar. Adukan dapat tercampur merata dan homogen. Beton segar SCC yang menggunakan tailing lebih homogen dan lebih mudah dikerjakan (workable) dibandingkan beton tanpa tailing. Hal ini dikarenakan tailing mampu mengisi celah diantara butiran agregat halus dan agregat kasar, sehingga beton SCC lebih homogen.

Passing ability merupakan kemampuan campuran beton segar untuk melewati tulangan. Sifat ini diperlukan pada saat adukan beton digunakan untuk membuat struktur dengan jarak tulangan yang rapat. Beton SCC yang mempunyai sifat passing ability yang baik, dapat melewati celah-celah tulangan yang rapat tanpa terjadi segregasi. Passing ability ratio merupakan rasio perbandingan dari beda ketinggian beton segar sebelum dan sesudah melalui rintangan. Nilai Passing ability ratio dihitung dengan Persamaan 1.

$$
\mathrm{PL}=\frac{\mathrm{H}_{2}}{\mathrm{H}_{1}}
$$

dimana PL: passing ability ratio, $\mathrm{H}_{1}$ : tinggi rata-rata beton segar pada bagian boks vertikal $(\mathrm{mm}), \mathrm{H}_{2}$ : tinggi rata-rata beton segar pada bagian ujung boks horizontal $(\mathrm{mm})$. Beton SCC yang memiliki nilai passing ability ratio lebih besar dari 0,80 menunjukkan bahwa beton SCC memliki kemampuan mengalir melewati celah tulangan dengan baik.

Hasil penelitian beton SCC dengan tailing sebagai substitusi agregat halus terlihat bahwa penggunaan tailing sebagai substitusi agregat halus pada beton SCC menghasilkan nilai passing ability dan segregation resistance lebih tinggi dibandingkan dengan beton SCC tanpa tailing. Kondisi ini terlihat dari nilai passing ability ratio hasil pengujian LBox mengalami kenaikan (Gambar 2). Hal ini berarti, kemampuan beton SCC dengan tailing untuk melewati celah tulangan yang rapat lebih baik dibandingkan dengan beton tanpa tailing. Adukan beton untuk semua variasi memenuhi syarat beton sebagai beton SCC seperti dalam ketentuan EFNARC yang mensyaratkan nilai h2/h1 sebesar $0,8-1,0$.

\section{Waktu ikat beton}

Waktu ikat awal merupakan kondisi, dimana beton mulai mengeras. Waktu ikat awal perlu diketahui untuk menentukan sampai seberapa lama waktu yang dibutuhkan beton untuk mengeras dari keadaan plastis. Waktu ikat awal penting untuk diketahui agar dapat ditentukan berapa lama beton dapat dikerjakan. Waktu ikat awal beton SCC dengan tailing sebagai substitusi agregat halus, disajikan pada Gambar 3 .
Hasil penelitian waktu ikat awal beton SCC dengan tailing sebagai substitusi agregat halus mempunyai kecenderungan memperlambat waktu ikat awal beton sebesar 10 menit dari waktu ikat awal beton tanpa tailing. Penggunaan tailing sebagai substitusi agregat halus sampai dengan $15 \%$ pada beton SCC mempunyai waktu ikat awal cenderung sama dengan beton SCC tanpa tailing.

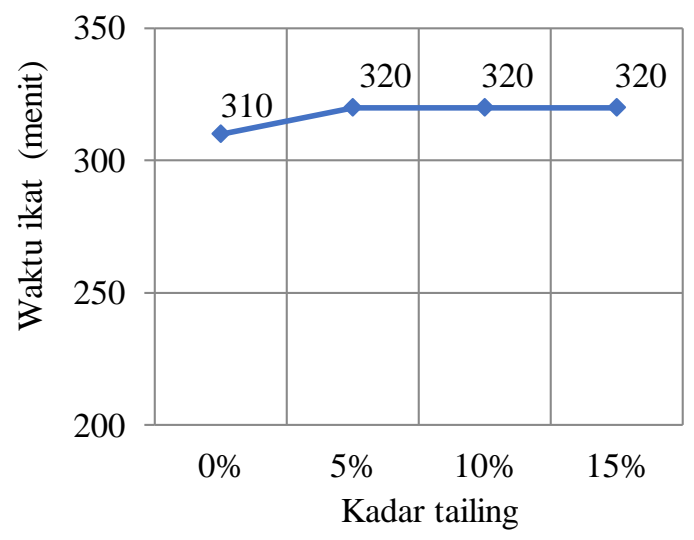

Gambar 3. Waktu ikat awal beton SCC dengan substitusi tailing

\section{Berat isi beton}

Berat isi beton digunakan untuk menghitung berat sendiri struktur. Semakin besar nilai berat isi, maka struktur memiliki berat sendiri yang besar pula. Hasil penelitian berat isi beton keras pada Gambar 4.

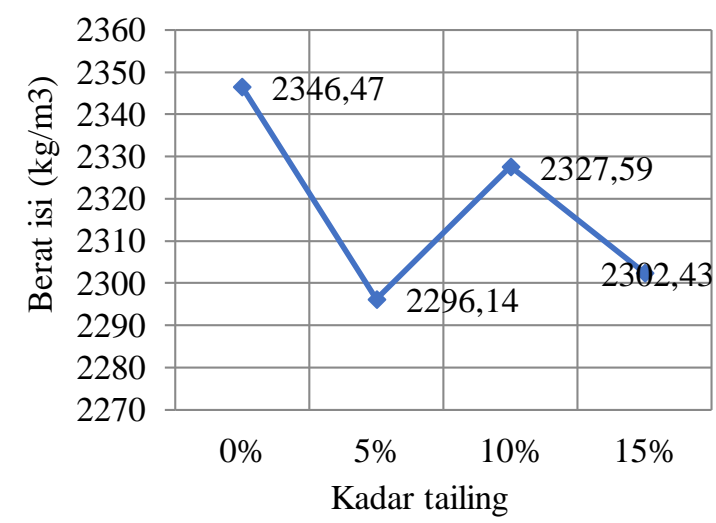

\section{Gambar 4. Berat isi beton SCC dengan substitusi tailing}

Berat isi beton merupakan nilai yang meyatakan perbandingan antara berat dan volume benda uji beton keras. Hasil penelitian penggunaan tailing sebagai substitusi agregat halus pada beton SCC menunjukkan bahwa penggunan tailing pada campuran beton SCC menyebabkan berat isi beton semakin menurun.

Hal ini berarti, beton dengan substitusi agregat halus tailing mempunyai berat struktur yang lebih 
ringan dibandingkan beton SCC tanpa tailing. Beton SCC dengan kadar tailing 5\% mempunyai berat lebih ringan sebesar $2,85 \%$, sedangkan beton dengan kadar tailing $10 \%$ mempunyai berat lebih ringan $3,42 \%$, serta beton dengan kadar tailing $15 \%$ beratnya lebih ringan sebesar $2,16 \%$.

Hasil penelitian ini sejalan dengan penelitian Amalia \& Murdiyoto, (2013), dimana penggunaan tailing pada bata beton berlubang juga memperkecil berat isi bata. Semakin banyak tailing yang menggantikan pasir pada bata beton berlubang, maka berat isi bata beton juga menurun (Amalia dan Murdiyoto,A.2013). Hasil penelitian penggunaan tailing sebagai bahan pengisi pada dinding beton pracetak juga menghasilkan dinding yang lebih ringan dibandingkan dinding tanpa tailing (Amalia \& Murdiyoto, 2014).

\section{Kuat tekan beton SCC}

Untuk mengetahui perkembangan kekuatan beton, kuat tekan diuji pada umur 3, 7, 14, dan 28 hari. Tujuan pengujian kuat tekan pada umur ini adalah untuk mengetahui perkembangan kekuatan beton, sehingga dapat ditentukan kapan cetakan beton dapat dibuka, struktur dapat dipasang atau struktur dapat menerima beban serta untuk mengetahui ketahanan beton pada umur muda. Hasil penelitian kuat tekan beton disajikan pada Tabel 2 dan Gambar 5.

Tabel 2. Kuat tekan beton SCC tailing

\begin{tabular}{ccccc}
\hline Kadar & \multicolumn{4}{c}{ Kuat tekan rata-rata (MPa) } \\
\cline { 2 - 5 } tailing & 3 hari & 7 hari & 14 hari & 28 hari \\
\hline $0 \%$ & 21,51 & 31,48 & 38,22 & 40,95 \\
$5 \%$ & 32,74 & 36,65 & 44,82 & 49,82 \\
$10 \%$ & 26,12 & 29,84 & 40,48 & 54,64 \\
$15 \%$ & 32,84 & 33,78 & 36,80 & 44,35 \\
\hline
\end{tabular}

Kuat tekan beton merupakan kemampuan beton di dalam memikul beban yang bekerja pada struktur. Kuat tekan beton sangat dipengaruhi oleh mutu agregat, mutu perekat dan komposisi adukannya serta lingkungan dimana beton tersebut digunakan. Hasil penelitian menunjukkan bahwa beton SCC yang menggunakan tailing sebagai substitusi agregat halus, mempunyai kuat tekan lebih tinggi dibandingkan beton tanpa tailing (Gambar 5).

Hal ini terlihat dari perkembangan kuat tekan beton mulai pada umur $3,7,14$, dan 28 hari, beton SCC yang menggunakan tailing mempunyai kuat tekan lebih tinggi dibandingkan beton tanpa tailing (Gambar 5).

Beton SCC dengan tailing, sampai dengan umur 28 hari juga tidak mengalami penurunan kekuatan. Hal ini terjadi karena tailing yang banyak mengandung silika atau senyawa $\mathrm{SiO}_{2}$ dapat mengeliminer $\mathrm{Ca}(\mathrm{OH})_{2}$ dan bereaksi membentuk $\mathrm{CSH}$ yang membuat beton semakin kedap dan kuat tekannya naik. Sebagaimana diketahui kalsium hidroksida adalah basa kuat, sehingga beton mudah diserang asam dan menimbulkan korosi kimia.

Dengan adanya pozolan maka peranan kalsium hidroksida akan diperkecil karena kalsium hidroksida akan bereaksi dengan silika dan alumina aktif yang berasal dari pozolan membentuk kalsium silikat hidrat dan kalsium alumina hidrat. Hal ini akan mengakibatkan ketahanan kimia dari beton bertambah besar karena berkurangnya kalsium hidroksida.

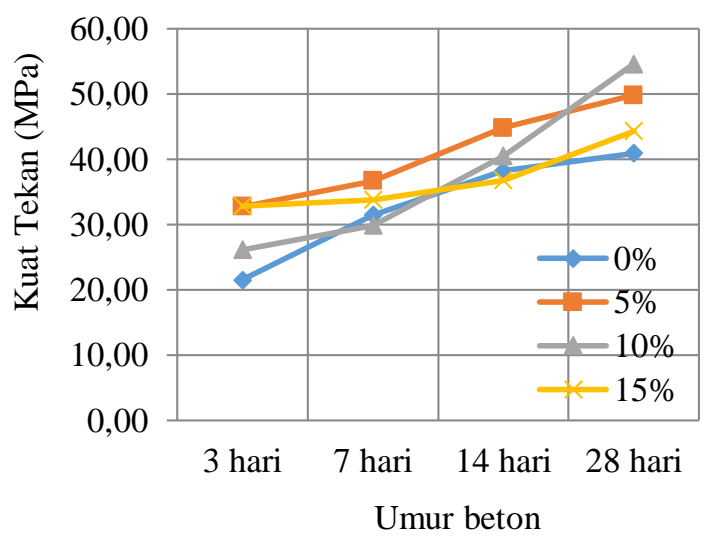

\section{Gambar 5. Kuat tekan beton SCC dengan substitusi tailing}

Selain itu, silika yang terkandung di dalam tailing juga akan membuat beton menjadi lebih padat sehingga permeabilitasnya juga rendah. Beton SCC dengan tailing memiliki ketahanan yang lebih baik terhadap serangan sulfat dibandingkan dengan beton SCC tanpa tailing. Reaksi antara pozzolan dan kalsium hidroksida yang ada pada semen akan menghasilkan suatu senyawa alumina gel, dimana silika gel ini merupakan bahan yang sangat baik dan melindungi beton dari serangan sulfat karena permeabilitas terhadap ion sulfat rendah.

Kuat tekan beton SCC pada umur 28 hari yang menggunakan tailing 5\%, mengalami peningkatan kuat tekan sebesar $48,82 \%$, beton SCC dengan kadar tailing $10 \%$ kuat tekan meningkat sebesar $53,64 \%$, sedangkan pada beton SCC dengan kadar tailing $15 \%$, kuat tekan naik sebesar sebesar 43,35\% dibandingkan beton tanpa tailing. Penggunaan tailing sebagai substitusi agregat halus pada beton SCC menghasilkan kuat tekan beton tertinggi sebesar 54,64 MPa pada beton SCC dengan kadar tailing 10\%. Dari hasil kuat tekan ini dapat dikatakan bahwa beton SCC yang menggunakan tailing sebagai substitusi agregat halus sampai dengan $15 \%$ mempunyai kekuatan yang lebih baik dibandingkan dengan beton tanpa tailing. 


\section{Kuat tarik beton SCC tailing}

Kuat tarik beton merupakan kemampuan beton di dalam menahan tegangan tarik yang terjadi pada beton. Beton merupakan jenis material yang getas, yang mempunyai kuat tekan tinggi, namun kuat tariknya rendah. Kuat tarik beton biasanya berkisar antara $10-15 \%$ dari kuat tekannya.

Oleh karena itu, di dalam perancangan struktur beton bertulang, terutama untuk menghitung kebutuhan penulangan, kuat tarik beton ini diabaikan, beton dianggap tidak mampu menahan tarik. Beton hanya berfungsi menahan tekan, sedangkan daerah tarik ditahan oleh tulangan. Namun demikian, beton harus mempunyai kuat tarik minimum seperti yang dipersyaratkan oleh Standar Nasional Indonesia, SNI T 122005 pasal 4.4.1.1.2, yitu sebesar $0,33 \sqrt{f c^{\prime}}$.

Walaupun tidak diperhitungkan, kuat tarik beton berfungsi menghambat retak akibat adanya penyusutan. Beton dengan kuat tarik tinggi mempunyai sifat tidak mudah retak bila terjadi penyusutan. Hasil penelitian kuat tarik beton SCC dengan substitusi agregat halus tailing disajikan pada Tabel 3.

Tabel 3. Kuat tarik beton SCC substitusi tailing

\begin{tabular}{ccc}
\hline $\begin{array}{c}\text { Kadar } \\
\text { tailing }\end{array}$ & $\begin{array}{c}\text { Kuat tarik } \\
\text { (MPa) }\end{array}$ & $\begin{array}{c}\text { Kuat tarik formula } \\
\text { SNI = 0,33.Vfc' (MPa) }\end{array}$ \\
\hline $0 \%$ & 3,84 & 2,11 \\
$5 \%$ & 3,43 & 2,33 \\
$10 \%$ & 2,24 & 2,44 \\
$15 \%$ & 2,65 & 2,20 \\
\hline
\end{tabular}

Dari Tabel 3 terlihat bahwa penggunaan tailing sebagai agregat halus pada beton SCC menyebabkan kuat tarik beton menurun. Semakin besar tailing yang digunakan sebagai substitusi agregat halus, kuat tarik beton semakin turun. Hal ini berarti penambahan tailing pada beton menyebabkan beton semakin getas. Kuat tarik beton tidak berbanding lurus dengan kuat tekannya, namun demikian kuat tarik beton berbanding lurus dengan akar kuadrat kuat tekannya. Kuat tarik beton SCC yang menggunakan tailing mempunyai kuat tarik lebih tinggi dibandingkan dengan kuat tarik yang dipersyaratkan SNI.

\section{Modulus elastisitas beton SCC}

Modulus elastisitas beton merupakan kemiringan garis singgung dari kondisi tegangan nol ke kondisi tegangan 0,45 f'c pada kurva tegangan-regangan beton. Modulus elastisitas beton dipengaruhi oleh jenis agregat, kelembaban benda uji beton, faktor air semen, umur beton dan temperaturnya. Secara umum, peningkatan kuat tekan beton seiring dengan peningkatan modulus elastisitasnya. Menurut pasal 10.5 SNI-03-2847 (2002) hubungan antara nilai modulus elastisitas beton normal dengan kuat tekan beton adalah $E_{c}=4700 \sqrt{f^{\prime} c}$. Hasil penelitian modulus elastisitas beton SCC dengan substitusi tailing sebagai agregat halus disajikan pada Tabel 4. Pengujian modulus elastisitas beton dilakukan dengan memberikan beban secara bertahap sampai mencapai beban $40 \%$ beban puncak. Pemendekan benda uji $(\Delta \mathrm{L})$ untuk menghitung regangan longitudinal diperoleh dari hasil pembacaan pada dial gauge yang dipasang pada benda uji. Nilai modulus elastisitas beton hasil eksperimen dibandingkan dengan modulus elastisitas teoritis formulasi SNI 03-2846 (2002) pasal 10.5.

Tabel 4. Modulus elastisitas beton SCC substitusi tailing

\begin{tabular}{ccc}
\hline $\begin{array}{c}\text { Kadar } \\
\text { tailing }\end{array}$ & $\begin{array}{c}\text { Modulus } \\
\text { elastisitas } \\
\text { (MPa) }\end{array}$ & $\begin{array}{c}\text { Modulus } \\
\text { elastisitas formula } \\
\text { SNI (MPa) }\end{array}$ \\
\hline $0 \%$ & $24.637,13$ & $27.740,94$ \\
$5 \%$ & $32.380,97$ & $33.095,80$ \\
$10 \%$ & $44.668,59$ & $31.775,03$ \\
$15 \%$ & $27.356,92$ & $31.288,98$ \\
\hline
\end{tabular}

Dari Tabel 4 terlihat bahwa modulus elastisitas beton SCC tertinggi dihasilkan oleh beton dengan kadar tailing 10\%. Modulus elastisitas beton berkaitan erat dengan FAS, kepadatan dan kuat tekan beton. Modulus elastisitas beton berhubungan erat dengan kuat tekan beton, dimana modulus elastisitas beton semakin tinggi seiring dengan meningkatnya kuat tekan beton. Beton SCC dengan kadar tailing 10\%, mempunyai kuat tekan lebih tinggi dibandingkan dengan beton tanpa tailing, sehingga dengan enrgi yang sama dihasilkan pemendekan dan regangan longitudinal yang lebih kecil dibandingkan dengan beton tanpa tailing. Regangan longitudinal yang kecil ini akan membuat nilai modulus elastisitas beton menjadi lebih tinggi. Selain itu, kuat tekan yang lebih tinggi menyebabkan kemampuan beton dalam mentrasfer tegangan semakin meningkat sehingga modulus elastisitasnya juga meningkat.

Beton SCC dengan kadar tailing $10 \%$ menghasilkan modulus elastisitas lebih tinggi dibandingkan dengan beton tanpa tailing. Kondisi ini juga berhubungan dengan kepadatan beton. Tailing yang mengandung silika mempunyai ketahanan terhadap garam sulfat lebih baik dibandingkan dengan beton SCC tanpa tailing. Selain itu, tailing mampu mengisi rongga di antara agregat, sehingga beton menjadi lebih padat. Pada kadar tailing $10 \%$, tailing mengisi secara optimum rongga di antara agregat tersebut sehingga kuat tekan dan modulus elastisitasnya meningkat. Dari 
Tabel 4 terlihat bahwa nilai modulus elastisitas beton untuk semua perlakuan hasil eksperimen mempunyai kecenderungan lebih kecil dibandingkan dengan modulus elastisitas teoritis menurut formulasi yang ditetapkan SNI-03-2847 (2002) pasal 10.5, hanya beton SCC dengan kadar tailing $10 \%$ yang menghasilkan modulus elastisitas lebih besar dibandingkan modulus elastisitas teoritis menurut formulasi SNI.

\section{Kuat Lentur beton SCC}

Hasil pengujian kuat lentur beton SCC disajikan pada Tabel 5. Kuat lentur beton merupakan kemampuan beton di dalam memikul beban lentur. Gaya dalam yang ditimbulkan akibat beban lentur adalah momen dan geser. Di dalam desain struktur beton bertulang, biasanya elemen struktur yang dominan memikul beban lentur adalah balok dan pelat.

Tabel 5. Kuat lentur beton SCC substitusi tailing

\begin{tabular}{lcc}
\hline $\begin{array}{l}\text { Kadar } \\
\text { Tailing }\end{array}$ & $\begin{array}{c}\text { Kuat lentur rata- } \\
\text { rata (MPa) }\end{array}$ & $\begin{array}{c}\text { Kuat lentur } \\
\text { formula SNI = } \\
\mathbf{0 , 6 . V f c '} \text { (MPa) }\end{array}$ \\
\hline $0 \%$ & 3,25 & 4,38 \\
$10 \%$ & 3,00 & 3,97 \\
$20 \%$ & 3,00 & 3,90 \\
$30 \%$ & 2,83 & 3,82 \\
\hline
\end{tabular}

Hasil penelitian menunjukkan bahwa penggunaan tailing sebagai substitusi agregat halus pada beton SCC menurunkan kuat lentur beton (Tabel 5). Kuat lentur beton turun sebesar 7,69\% pada beton SCC dengan kadar tailing sebesar $10 \%$, beton SCC dengan kadar tailing turun sebesar 5,13\%, sedangkan beton dengan kadar tailing 30\%, kuat lentur turun sebesar $12,82 \%$. Kuat lentur berhubungan erat dengan kuat tarik dan kuat tekan beton. Semakin tinggi kuat tekan beton, maka kuat lentur dan kuat tariknya semakin tinggi. Di dalam desain struktur beton bertulang, terutama untuk menghitung kebutuhan tulangan, kuat lentur beton diabaikan. Daerah tarik yang terjadi akibat momen lentur, ditahan seluruhnya oleh tulangan. Beton dianggap tidak mampu menahan tarik. Namun demikian, beton harus memenuhi persyaratan kuat tarik lentur seperti dalam ketentuan SNI T 12-2004 pasal 4.4.1.1.3 yaitu sebesar $0,6 \sqrt{f c^{\prime}}$. Hasil penelitian menunjukkan semua benda uji beton SCC tidak memenuhi syarat minimum kuat lentur ketentuan SNI (Tabel 5).

\section{Kesimpulan}

Berdasarkan hasil penelitian dan pembahasan dapat diambil kesimpulan bahwa penggunaan tailing sebagai substitusi agregat halus pada beton SCC, mempunyai workability yang baik. Semakin besar penambahan tailing akan menurunkan sifat passing ability dan filling ability. Penggunaan tailing sampai dengan $15 \%$ masih memenuhi syarat sifat filling ability dan passing ability beton SCC.

Waktu ikat awal beton SCC dengan tailing sebagai substitusi agregat halus pada beton SCC lebih lama 10 menit dibandingkan beton SCC tanpa tailing. Berat isi beton SCC dengan tailing lebih ringan dibandingkan beton SCC tanpa tailing. (4) Beton SCC yang menggunakan tailing sampai dengan $15 \%$ mempunyai durabilitas lebih baik dibandingkan beton tanpa tailing.

Kuat tekan beton SCC paling tinggi dicapai oleh beton dengan kadar tailing $10 \%$ sebesar 54,64 MPa pada umur 28 hari. Kuat tekan terrendah dihasilkan oleh beton SCC tanpa tailing, sebesar 40,95 MPa. Penggunaan tailing sebagai substitusi agregat agregat halus pada beton SCC menyebabkan kuat tarik dan kuat lentur beton. Kuat Tarik beton SCC dengan tailing memenuhi persyaratan SNI 28472002. Beton SCC dengan substitusi tailing mempunyai modulus elastisitas lebih tinggi dibandingkan dengan beton tanpa tailing. Komposisi optimum tailing pada Beton SCC dicapai pada kadar $10 \%$, dimana pada komposisi ini dihasilkan beton SCC yang mempunyai kualitas paling baik.

\section{Ucapan Terima Kasih}

Ucapan terima kasih ditujukan kepada Politeknik Negeri Jakarta yang telah memberikan dana penelitian ini melalui DIPA PNJ Penelitian Produk Terapan Tahun Anggaran 2017. Ucapan terima kasih juga disampaikan kepada Kepala laboratorium dan Laboran Teknik Sipil yang telah membantu pembuatan benda uji.

\section{Daftar Pustaka}

Amalia \& Murdiyoto, A. (2013). Quality of Hollow Concrete Brick with Tailing of Gold Mining UPBE Pongkor. Paper presented of Annual South East Asian International Seminar, State Polytechnic of Jakarta, Depok, 22 November, 8-13.

Amalia \& Murdiyoto, A. (2014). Precast Concrete Panel with Substitution of Fine Agregate Mining Gold Tailing Pongkor. Paper presented of Annual South East Asian International Seminar, State Polytechnic of Jakarta, Depok, 12 November, 2838.

American Standard Testing and Material (ASTM). (1993). Standard specification for concrete aggregates. ASTM C33-03-1993. 
Atan, M. N., \& Awang, H. (2011). The Compressive And Flexural Strengths of SelfCompacting Concrete Using Raw Rice Husk Ash. Journal of Engineering Science and Technology, 6(6), $720-732$.

Badan Standardisasi Nasional (BSN). (2002). Tata cara perhitungan struktur beton untuk bangunan gedung (beta version), SNI 03-2847-2002.

Badan Standardisasi Nasional (BSN). (2004). Perencanaan struktur beton untuk jembatan, SNI T-12-2004.

Borsoi, A., Collepardi M., Collepardi S., Croce E.N, \& Passuelo A. (2006). Influence of Viscocity Modifying Admixture on The Composition of SCC. Paper presented of International Conference on Superplastisizer and Other Chemical Admixtures in Concrete, American Concrete Institute, Sorrento, Italy, 253-261.

Borsoi, A., Collepardi M., Collepardi S., Troli L., \& Zanardi L. (2007). Low Heat, High-Strength, Durable Self-Consolidating Concretes. Paper presented of International Conference on Recent Advances in Concrete Technology, American Concrete Institute Warsaw, Poland, 399-408.

Bouziani, T., Bederina, M., \& Hadjoudja, M. (2012). Effect of Dune Sand on the Properties of Flowing Sand-Concrete (FSC). International Journal of Concrete Structures and Materials, 6(1), 59-64.

Collepardi, M. (2005). Self-Consolidating Concrete in the Presence of Fly-Ash for Massive Structures. Paper presented of Second International Symposium on Concrete Tecnology for Sustainable, Development with Emphasis on Infrastructure, Hyderabad, India, 597-604.

Collepardi, M, Borsoi A., Collepardi S., \& Troli R. (2007). Recent Developments of Special SelfCompacting Concretes. Paper presented of Second
International Symposium on Concrete Tecnology for Sustainable, American Concrete Institute, Warsaw, Poland, 497-504.

Dhiyaneshwaran, S., Ramanathan, P., Baskar, I. \& Venkatasubramani, R. (2013). Study on Durability Characteristics of Self-Compacting Concrete with Fly Ash. Jordan Journal of Civil Engineering, 7(3), 45-55. Retrieved April 10, 2015, from https://www.iiste.org/Journals/index.php/JJCE/ind ex

Dubey, R. \& Kumar, R. (2012). Effect of superplasticizer dosages on compressive strength of self compacting concrete, International Journal Of Civil And Structural Engineering, 3(2), 360-366. Retrieved April 14, 2015, from http://www.ipublishing.co.in/jcserissues.html.

European Federation of National Associations Representing for Concrete (EFNARC). (2002). Specification and Guidelines for Self-Compacting Concrete. Retrieved April 10, 2015, from http://www.efnarc.org/pdf/SandGforSCC.PDF.

Grdić, Z., Despotović, I., \& Topličić-Ćurčić, G. (2008). Properties of Self-Compacting Concrete with Different Types of Additives. Facta universitatis-series: Architecture and Civil Engineering, 6(2), 173-177.

Okamura, H \& Ouchi, M. (2003). Self Compacting Concrete. Journal of Concrete Technology, 1(1), 515 .

Saing, Z. (2008). Sifat Pemanfaatan Tailing Sebagai Alternatif Perkerasan Jalan, Jurnal Teknik Dintek 1 (2), 53-61.

Troli, R, Borsoi A., Collepardi S., Fazio G., Collepardi M., Monosi S. (2005). Self-Compacting / Curing / Compressing Concrete. Paper presented of $6^{\text {th }}$ International Congress, Global Construction, Ultimate Concrete Opportunities, Dundee, U.K, 6778 . 